\title{
Why Brain Drain in the Nigerian Health Sector?
}

\author{
Agba A. M. Ogaboh ${ }^{1 *}$, H. T. Udom², Ide T. Eka ${ }^{3}$ \\ ${ }^{1}$ Lecturer, Department of Sociology \\ University of Calabar, Nigeria \\ ${ }^{2}$ Department of Social Work, University of Nigeria, \\ Nsukka, Nigeria \\ ${ }^{3}$ Department of Sociology \\ University of Calabar, Nigeria \\ *Corresponding author's email: ogabohagbagroup [AT] yahoo.com
}

\begin{abstract}
One prime problem facing developing countries is the exodus of its skilled labour to advanced nations for greener pasture. This study therefore examines whether remuneration, workers' safety and working equipment accounts for brain flight among health practitioners in Nigeria. Survey research design was used. The research approach was predominantly quantitative with less qualitative components incorporated for participants to give recommendations. The study statistically analyzed data using linear regression, and the results showed that remuneration, workers' safety and working tools significantly elicited brain drain among health personnel. We suggested among others critical policy reforms that would address inadequacies in working environments in public and private hospitals.
\end{abstract}

Keywords--- Brain drain, remuneration, workers' safety, working equipment

\section{INTRODUCTION}

One major problem facing developing nations is brain-drain of skilled labour. Brain-drain is largely linked with the migration of workers from their current location (home country) to another where their skills are well paid for. Developing nations such as Nigeria largely experience this mishap especially in the health and educational sectors. More than half of Nigerian doctors lived and practiced abroad. Paradoxically, Canada, the United States, and Britain, with large human resources are centres of attraction for Nigeria's health professionals (Agba, Mboto, Agba, 2013). Medical professionals migrating from Nigeria to other countries remains a significant constraint to healthcare delivery. According to the reports of Mensah, Mackintosh, and Henry (2005); Agba, Ushie, Ushie, Bassey and Agba (2009); and Mills, Kanters, Hagopian, Bansback, Nachega, Alberton, Au-Yeung, Mtambo, Bourgeault, Luboga, Hogg and Ford (2011), migration of medical personnel intensifies human resource crisis and contributes to global health disparity. It counts for billions of US\$ human capital loss in sub-Saharan African countries (World Health Organisation, 2006 ${ }^{\mathrm{a} \& \mathrm{~b}}$ ).

Extant studies documented on migration of healthcare professionals identified "push" and "pull" factors as determinants of migration decisions. "Push factors" according to Naicker, Plange-Rhule, Tutt, and Eastwood (2009) "are those factors that occur within the county of origin, motivating professionals to leave. While 'pull factors' are the unintended and/or deliberate actions that attract health professionals originating from the recipient country's policies and actions". The push factors are: lack of established career opportunities, poor remuneration and conditions of service, low job satisfaction, management shortcomings, civil unrest, and personal security. The pull factors include increased demand for health professionals in recipient countries, (for instance, the need of care for aging populations) financial rewards, training opportunities and career advancement, and improved working conditions (Naicker, et al., 2009).

While most literature and policy analysts did generally support remuneration as prime cause of brain drain among health practitioners, attempts at empirical validation have been limited, and the evidence concerning the rationale behind this exodus of health professional remains not only inadequate but also largely inconclusive. This study therefore seeks to validate previous studies by providing empirical data on the relationship between remuneration, workers' safety, working equipment and brain drain of health professional in public hospitals in Cross River State, Nigeria. Specifically, the study investigates whether remuneration is responsible for brain drain among health practitioners, determines the relationship between workers' safety and brain drain among health practitioners, as well as establish whether working equipment influences brain drain among health practitioners. 


\section{LITERATURE REVIEW}

\section{Remuneration and brain drain among health care practitioners}

Differentials in wages between rich and poor countries offer a pull towards the developed nations (Agba \& Ushie, 2013; Agba, et al., 2013; Attah \& Angioha, 2019). Tessema (2010) maintained that, health personnel feel that salaries they earn abroad cannot be matched with those earned locally. Tessema points out that highly skilled health personnel who have migrated to developed countries are lured mainly by higher salaries and entitlements. Kiraya (2000) and Tessema (2010) posit that wage differentials is a major cause of brain drain. Khwaja and Scaramozzino (2003) acknowledged that an important explanation for brain drain in the healthcare sector lies largely on the wage gaps between technologically advanced countries and unindustrialized countries. As a result of poor economic situation in developing nations, most professional are paid wages that are considerably lower than that of their colleagues in developed nations. Professionals in developing nations, especially Africa, only manage to make a living from paltry wages they earn and a lot more live below poverty contour. Dimaya, McEwen, Curry and Bradley (2012) asserts that, in the health sector, higher wages, better employment opportunities and technologies in industrialised nations motivates health care professionals in developing nations to migrate.

Kiraya (2000) studied brain drain among Zambian health workers and asserts that nurses receive an average monthly remuneration of 1.1 million Kwacha (US\$ 229), clinical officials receive a salary of 1.1 million Kwacha (US\$ 229). The remunerations as identified by Lusale (2007) includes "monthly salary, regular uniform and night allowances paid as composite every month. In comparison with other governmental staff like pharmacists, technologists, environmental health technologists, and radiographers with similar duration of training, the salaries can be seen to be reasonable". However, they are low when compared with the monthly food basket requirements estimated to be in the range of 1.4 million Kwacha (US\$ 350) for a family of six (6), and cannot cater for decent housing, transportation, and other basic amenities such as water and electricity (Awases, Gbany, Nyan, \& Chatora, 2004; Hamada, Maben, McPake, \& Hanson, 2009). According to this, low wages are significant to the migration of medical personnel to where remunerations are better. Padarath and Chamberlain (2003) in their article "health personnel in sub-Southern Africa: Confronted with mal-distribution and brain drain", points that remuneration levels are potentially the most influential factors in brain drain among health workers.

\section{Safe working environment and brain drain}

Safe working environment is a fundamental labour rights of the worker. Regrettably, good working conditions in most government owned establishments are not always guaranteed. In most cases, employees are subjected to hazardous or substandard working conditions. Reports from Agba, Ushie, Agba and Nkpoyen (2010) and the International Labour Organization (ILO, 2012), noted that employees should be protected from workplace injury, diseases and sickness. This is because workplaces accounts "for more than 2.3 million deaths per year, of which 350,000 are fatal accidents and nearly 2 million are due to work-related diseases". Reports documented on workers' safety further noted that "in the United States, there were 6,026 fatal work injuries and approximately 3.8 million nonfatal injuries in 1998, resulting in an estimated 80 million production days lost for that year and almost 60 million days in future years (Bureau of Labour Statistics, 2000; United States Census Bureau, 2000). In 1999, there were 833 work-related fatalities in Canada, while 379,395 Canadian workers suffered injuries serious enough to be compensated either for wages lost" (Association of Workers' Compensation Boards of Canada, 2000). This scenario is worst in Africa where workers suffered hazards and death at workplace and are largely ignored, not reported and victims not compensated.

According to Kampert (2008), "employers who pay attention to all the details that affect the welfare of their workers, including their work environment are likely to retain the best people, save cost, enjoy cordial work relation, and improve the productivity of their workers". Correspondingly, Ndagana (2007) and Sakir and Fajonyomi (2007) included clean and siren environment as well as good working relationship between employer and employee as part of the incentive packages due to workers. Working environment has the capacity to dampen or boost the morale of employees' and can significantly contribute to brain drain among health workers.

\section{Working equipment and brain drain among health practitioners}

United States, United Kingdom, and Australia provide good infrastructures, and funding in their health system, unlike developing nations where these facilities are near absence (Agba \& Ushie, 2010; Carvantes \& Domique 2002; Meyer \& Brain, 1999; Ukwayi, Angioha, \& Ojong-Ejoh, 2018; Agba, Eteng \& Coker, 2016). This problem according to Hall (2005) are largely responsible for brain drain among medical practitioners. Ikenwilo (2007) asserts that the issue of inadequate facilities is a common feature of most developing nations. These inadequacies most times push medical practitioners to move to countries where these facilities are available. Manongi, Marchant and Bygbjerg (2006) maintained that lack of laboratory facilities and funds to support innovation accords for brain drain. 


\section{THEORETICAL FRAMEWORK}

\section{World System Theory}

The world systems theory was developed by Immanuel Wallerstein in (1970). Other world system thinkers are Andre Gunder Frank, Cardoso, Rodney, Samir Amin, Falleto, and Dos Santos. The theory assumes that the economic system is divided into two - the one who gives (the exploited) and the one who takes (the benefiter). It further puts that the current world system operates on a bounded structure with diverse rules that helps to bring together sub-groups of the entire system (society). It views the entire system as a web of global capitalism and is more-larger than a single juridical political unit (Lechtner, 2009).

The theory borrows heavily from modernisation theory that adopts the principle of 'dependency', between the 'haves' and the 'have-not'. It was noted that, before the current world system, the $16^{\text {th }}$ century events gave upper hands to the Western nations; where a great capital base was created with advances from technological innovations as well as globalinternational affairs. With this, the Western control spheres of global politics. Today, the world system according to Lechtner (2009) is divided between the 'core', 'periphery' and 'semi-periphery'. The core nations (Western countries especially America and Europe) are highly influential in global affairs, have sophisticated technological systems, and manufacturer of complex products. Periphery nations (Southern nations such as Nigeria, Ghana, Serbia, and the Haiti) are the production nerves, who provides raw materials like cheap labour and agricultural products to the world system. The periphery nations are technologically poor, lack sway in global affairs, have limited capital base, as well as buys the finished products and services from the core at high prices. The semi-periphery nations are in-between. Although struggling, but are better-off the periphery. They are found across different areas of the world. They act as core (buffer) to the periphery these include countries of Brazil, China, India, South Korea, and South Africa. Core and periphery nations may exist next to each other, but the differences can be identified by the extents and quality of their influence on global policies, workers' wages, technological production, and valuation of products (Halsall, 1997).

Brain drain seems to be an unavoidable and even expected consequence of current power relations within the modern day capitalist 'world system'. It posits that the migration of persons, despite the country's migration regulations, follows the well-trodden international flows of commodities, capital, services and information, all spawned and reproduced by an expanding global market. The theory is however significant to the present study on brain drain because it points out the push and pull factors that encourage the migration of doctors and nurses from developing countries to Western world.

\section{METHODS}

The survey research design that allows for drawing of inferences and generalisation of research findings was adopted in this study. The study was carried out in public hospitals situated in Calabar, Cross River State, Nigeria. The target population of the study comprises of all doctors and nurses in public hospitals in Calabar, Cross River State, Nigeria. Doctors and nurses are among health practitioners who migrate to developed countries for greener pastures. The sample for this study was drawn using stratified random sampling technique. Specifically, the proportional method was adopted, where each department serves as a stratum. The proportional stratified random sampling technique was adopted in selecting four units in the selected public hospitals. These units include - the Orthopaedic, Family Clinic, Eye Clinic, and Emergency Ward. Purposive sampling technique was adopted in selecting doctors and nurses from each of the departments

The instrument for data collection was questionnaire titled "Working Conditions and Brain Drain Questionnaire (WCBDQ)". The questionnaire was divided into sections. Section 1 gathered demographic information of health workers to include their age, sex, educational level, position, and department. Section 2 and 3 elucidate information to measure the relationship between working conditions and brain drain. Each item requires the respondents to respond on a Likert scale of - Strongly agree (SA), Agree (A), Disagree (D), Strongly disagree (SD). Data generated were coded and analysed using the Statistical Package of Social Sciences (SPSS version 21). Analysis of data was based on the research hypotheses formulated. The statistical test employed was linear regression.

\section{RESULTS}

The distribution of socio-demographic features of respondents in this study is presented in Table 1. It shows that out of 249 participants, 153 responses representing 61.4 per cent were male while 96 responses representing 38.6 per cent were female. The spread of respondents in terms of age shows that 37 responses representing 14.9 per cent were below 30 years, 124 responses representing 49.8 per cent are between the ages of 30-40 years, 25 responses representing 10.0 per cent are between the ages of 41-50 years, while 63 responses representing 25.3 per cent are between 51 years and above. Respondents' marital status reveals that 59 responses representing 23.7 percent are single, 157 responses representing 63.1 per cent are married, while 13 responses representing 5.2 per cent are divorced or separated, and 20 participants representing 8.0 per cent were widowed. The distribution of respondents based on length of service shows that 23 responses representing 9.2 per cent of the total population had worked for 1-5 years, 136 responses representing 54.6 per cent of the population had worked for 6-10 years, 63 responses representing 25.4 per cent had worked for 11-15 years, while 27 
responses representing 10.8 per cent had worked for 16 years and above. The compartmentalization of respondents in respect to religion indicates that 214 responses representing 85.9 per cent are Christians while 35 responses representing 14.1 per cent are Islam. None indicated for the African Traditional Religion (ATR).

Table 1: Socio-demographic features and distribution of respondents

\begin{tabular}{llcc}
\hline Variable & Category & Frequency & Percentage \\
\hline Gender & Male & 153 & 41.4 \\
& Female & 93 & 38.6 \\
Age & Total & 249 & 100 \\
& Below 30 years & 37 & 14.9 \\
& $30-40$ years & 124 & 49.8 \\
& $41-50$ years & 25 & 10.0 \\
Marital status & 51 years + & 63 & 25.3 \\
& Total & 249 & 100 \\
& Single & 59 & 23.7 \\
& Married & 157 & 63.1 \\
& Divorced/separated & 13 & 5.2 \\
Length of service & Widowed & 20 & 8.0 \\
& Total & 249 & 100 \\
& $1-5$ years & 23 & 9.2 \\
& $6-10$ years & 136 & 54.6 \\
& $11-15$ years & 63 & 25.4 \\
Religion & 16 years + & 27 & 10.8 \\
& Total & 249 & 100 \\
& Christian & 214 & 85.9 \\
& Islam & 35 & 14.1 \\
& ATR & - & - \\
& Total & 249 & 100 \\
\hline
\end{tabular}

Source: Fieldwork, 2019

Responses on remuneration as a determinant of brain-drain among health practitioners as presented in Table 2 shows that majority either strongly agreed or agreed to four out of the five items in the sub-scale. The items are: Item 1 (Unsatisfactory pay package is responsible for brain drain among health practitioners), item 2 (Inadequate remuneration provokes migration among medical practitioners), item 3 (Medical practitioners in developed nations earn better remuneration compared to their colleagues in home country (Nigeria)) and item 4 (Health practitioners migrate to foreign countries for enhanced salary package). On the other hand, more than half of the respondents either strongly disagreed or disagreed to item 5 in the sub-scales (Brain drain among health practitioners is not associated to poor remuneration).

Table 2: Response on remuneration and brain drain of health practitioners

\begin{tabular}{|c|c|c|c|c|c|}
\hline $\mathrm{S} / \mathrm{N}$ & ITEMS & $\mathrm{SA}$ & $\mathrm{A}$ & $\mathrm{D}$ & SD \\
\hline 1 & $\begin{array}{l}\text { Unsatisfactory pay package is responsible for brain } \\
\text { drain among health practitioners }\end{array}$ & $\begin{array}{c}147 \\
(59.0)\end{array}$ & $\begin{array}{c}50 \\
(20.1)\end{array}$ & $\begin{array}{c}13 \\
(5.2)\end{array}$ & $\begin{array}{c}39 \\
(15.7)\end{array}$ \\
\hline 2 & $\begin{array}{l}\text { Inadequate remuneration provokes migration among } \\
\text { medical practitioners }\end{array}$ & $\begin{array}{c}132 \\
(53.0)\end{array}$ & $\begin{array}{c}55 \\
(22.1)\end{array}$ & $\begin{array}{c}38 \\
(15.3)\end{array}$ & $\begin{array}{c}24 \\
(9.6)\end{array}$ \\
\hline 3 & $\begin{array}{l}\text { Medical practitioners in developed nations earn better } \\
\text { remuneration compared to their colleagues in home } \\
\text { country (Nigeria) }\end{array}$ & $\begin{array}{c}182 \\
(73.1)\end{array}$ & $\begin{array}{c}35 \\
(14.1)\end{array}$ & $\begin{array}{c}14 \\
(4.6)\end{array}$ & $\begin{array}{c}18 \\
(7.2)\end{array}$ \\
\hline 4 & $\begin{array}{l}\text { Health practitioners migrate to foreign countries for } \\
\text { enhanced salary package }\end{array}$ & $\begin{array}{c}128 \\
(51.4)\end{array}$ & $\begin{array}{c}66 \\
(26.5)\end{array}$ & $\begin{array}{c}25 \\
(10.0)\end{array}$ & $\begin{array}{c}30 \\
(12.1)\end{array}$ \\
\hline 5 & $\begin{array}{l}\text { Brain rain among health practitioners is not associated } \\
\text { to poor remuneration }\end{array}$ & $35(14.1)$ & $\begin{array}{c}15 \\
(6.0)\end{array}$ & $\begin{array}{c}43 \\
(17.2)\end{array}$ & $\begin{array}{l}156 \\
(62.7)\end{array}$ \\
\hline
\end{tabular}

Source: Fieldwork, 2019

Table 3 showed response on workers' safety. Majority either strongly agreed or agreed to four out of the five items in the sub-scale. The items are: Item 1 (Migration of health professionals is prevalent where workers feel threatened 
in their work places), item 2 (Medical practitioners travel to countries where workers' safety are held in high esteem), item 3 (High-quality care of health professionals in receiving countries is responsible for continuous brain drain among doctors and nurses) and item 4 (Health professionals migrate because they are dissatisfied with the safety precautions in their hospitals). More than half of the respondents either strongly disagreed or disagreed to items 5 in the sub-scale (Workers safety does not stimulate migration among health practitioners).

Table 3: Response on workers' safety and brain drain of health practitioners

\begin{tabular}{|c|c|c|c|c|c|}
\hline $\mathrm{S} / \mathrm{N}$ & ITEMS & SA & $\mathrm{A}$ & $\mathrm{D}$ & SD \\
\hline 1 & $\begin{array}{l}\text { Migration of health professionals is prevalent where } \\
\text { workers feel threatened in their work places }\end{array}$ & $84(33.7)$ & $\begin{array}{c}82 \\
(32.9)\end{array}$ & $\begin{array}{c}38 \\
(15.3)\end{array}$ & $\begin{array}{c}45 \\
(18.1)\end{array}$ \\
\hline 2 & $\begin{array}{l}\text { Medical practitioners travel to countries where } \\
\text { workers safety are held in high esteem }\end{array}$ & $\begin{array}{c}175 \\
(70.3)\end{array}$ & $\begin{array}{c}42 \\
(16.9)\end{array}$ & $\begin{array}{c}12 \\
(4.8)\end{array}$ & $\begin{array}{c}20 \\
(8.0)\end{array}$ \\
\hline 3 & $\begin{array}{l}\text { High-quality care of health professionals in } \\
\text { receiving countries is responsible for continuous } \\
\text { brain drain among doctors and nurses }\end{array}$ & $\begin{array}{c}183 \\
(73.5)\end{array}$ & $\begin{array}{c}38 \\
(15.3)\end{array}$ & $\begin{array}{c}13 \\
(5.2)\end{array}$ & $\begin{array}{c}15 \\
(6.0)\end{array}$ \\
\hline 4 & $\begin{array}{l}\text { Health professionals migrate because they are } \\
\text { dissatisfied with the safety precautions in their } \\
\text { hospitals }\end{array}$ & $\begin{array}{c}147 \\
(59.0)\end{array}$ & $\begin{array}{c}43 \\
(17.3)\end{array}$ & $\begin{array}{c}39 \\
(15.7)\end{array}$ & $\begin{array}{c}20 \\
(8.0)\end{array}$ \\
\hline 5 & $\begin{array}{l}\text { Workers safety does not stimulate migration among } \\
\text { health practitioners }\end{array}$ & $41(16.5)$ & $\begin{array}{c}20 \\
(8.0)\end{array}$ & $\begin{array}{c}48 \\
(19.3)\end{array}$ & $\begin{array}{c}140 \\
(56.2)\end{array}$ \\
\hline
\end{tabular}

Source: Fieldwork, 2019

Table 4 shows responses of participants to the sub-scale on health equipment and brain drain. More than half percentage of the respondents indicated that they either strongly agreed or agreed to the 5 item of the sub-scale. These items are: items 1, (Non-availability or near absence of health facilities leads to brain drain among health practitioners), item 2 (Inadequate infrastructural facilities is responsible for migration of doctors and nurses), Items 3 (Failure of hospital management to provide essential working tools results to brain drain among health professionals), item 4 (Inability of management to maintain as well as replace damaged equipment leads to brain drain among health practitioners) and item 5 (Health practitioners are likely to migrate to countries that offers better medical equipment).

Table 4: Response on health equipment and brain drain of health practitioners

\begin{tabular}{|c|c|c|c|c|c|}
\hline $\mathrm{S} / \mathrm{N}$ & ITEMS & $\mathrm{SA}$ & $\mathrm{A}$ & $\mathrm{D}$ & SD \\
\hline 1 & $\begin{array}{l}\text { Non-availability or near absence of health facilities } \\
\text { leads to brain drain among health practitioners }\end{array}$ & $\begin{array}{c}132 \\
(53.0)\end{array}$ & $\begin{array}{c}38 \\
(15.3)\end{array}$ & $\begin{array}{c}24 \\
(9.6)\end{array}$ & $\begin{array}{c}55 \\
(22.1)\end{array}$ \\
\hline 2 & $\begin{array}{l}\text { Inadequate infrastructural facilities is responsible for } \\
\text { migration of doctors and nurses }\end{array}$ & $\begin{array}{c}183 \\
(73.5)\end{array}$ & $\begin{array}{c}13 \\
(5.2)\end{array}$ & $\begin{array}{l}15 \\
(6.0)\end{array}$ & $\begin{array}{c}38 \\
(15.3)\end{array}$ \\
\hline 3 & $\begin{array}{l}\text { Failure of hospital management to provide essential } \\
\text { working tools results to brain drain among health } \\
\text { professionals }\end{array}$ & $\begin{array}{c}128 \\
(51.4)\end{array}$ & $\begin{array}{c}66 \\
(26.5)\end{array}$ & $\begin{array}{c}25 \\
(10.0)\end{array}$ & $\begin{array}{c}30 \\
(12.1)\end{array}$ \\
\hline 4 & $\begin{array}{l}\text { Inability of management to maintain as well as replace } \\
\text { damaged equipment leads to brain drain among health } \\
\text { practitioners }\end{array}$ & $\begin{array}{c}140 \\
(56.2)\end{array}$ & $\begin{array}{c}50 \\
(20.1)\end{array}$ & $\begin{array}{c}30 \\
(12.1)\end{array}$ & $\begin{array}{c}29 \\
(11.6)\end{array}$ \\
\hline 5 & $\begin{array}{l}\text { health practitioners are likely to migrate to countries } \\
\text { that offers better medical equipment }\end{array}$ & $\begin{array}{c}145 \\
(58.2) \\
\end{array}$ & $\begin{array}{c}75 \\
(30.1)\end{array}$ & $\begin{array}{c}13 \\
(5.2)\end{array}$ & $16(6.4)$ \\
\hline
\end{tabular}

Source: Fieldwork, 2019

Table 5 revealed responses of participants to the sub-scale on brain drain. Most respondents indicated that they either strongly agreed or agreed to all the five items in this sub-scale. These items are: Item 1 (Brain drain is not a common practice among health professionals), item 2 (Brain drain of health professionals is a serious challenge facing the country's health sector), item 3 (Doctors and nurses who desire better working conditions migrate to countries where they are available), item 4 (Enhanced condition of service in receiving countries encourages migration among medical practitioners), Items 5 (Health professionals who migrate are regarded as the most talented and are said to seek greener pastures in developed countries where they perceive economic opportunities and working conditions to be better and enhanced). 
Table 5: Response on why brain drain exists among health practitioners

\begin{tabular}{|c|c|c|c|c|c|}
\hline $\mathrm{S} / \mathrm{N}$ & ITEMS & SA & $\mathrm{A}$ & $S$ & SD \\
\hline 1 & $\begin{array}{l}\text { Brain drain is not a common practice among health } \\
\text { professionals }\end{array}$ & $\begin{array}{c}35 \\
(14.1)\end{array}$ & $\begin{array}{c}15 \\
(6.0)\end{array}$ & $\begin{array}{c}43 \\
(17.2)\end{array}$ & $\begin{array}{c}156 \\
(62.7)\end{array}$ \\
\hline 2 & $\begin{array}{l}\text { Brain drain of health professionals is a serious challenge } \\
\text { facing the country's health sector }\end{array}$ & $\begin{array}{c}135 \\
(54.2)\end{array}$ & $\begin{array}{c}75 \\
(30.1)\end{array}$ & $\begin{array}{c}23 \\
(9.2)\end{array}$ & $16(6.4)$ \\
\hline 3 & $\begin{array}{l}\text { Doctors and nurses who desire better working } \\
\text { conditions migrate to countries where they are available }\end{array}$ & $\begin{array}{c}145 \\
(58.2)\end{array}$ & $\begin{array}{c}57 \\
(23.0)\end{array}$ & $\begin{array}{c}21 \\
(8.4)\end{array}$ & $\begin{array}{c}26 \\
(10.4)\end{array}$ \\
\hline 4 & $\begin{array}{l}\text { Enhanced condition of service in receiving countries } \\
\text { encourages migration among health practitioners }\end{array}$ & $\begin{array}{c}128 \\
(51.4)\end{array}$ & $\begin{array}{c}66 \\
(26.5)\end{array}$ & $\begin{array}{c}25 \\
(10.0)\end{array}$ & $\begin{array}{c}30 \\
(12.1)\end{array}$ \\
\hline 5 & $\begin{array}{l}\text { Health professionals who migrate are regarded as the } \\
\text { most talented and are said to seek greener pastures in } \\
\text { developed countries where they perceive economic } \\
\text { opportunities and working conditions to be better and } \\
\text { enhanced. }\end{array}$ & $\begin{array}{c}147 \\
(59.0)\end{array}$ & $\begin{array}{c}43 \\
(17.3)\end{array}$ & $\begin{array}{c}39 \\
(15.7)\end{array}$ & $20(8.0)$ \\
\hline
\end{tabular}

Source: Fieldwork, 2019

\section{TEST OF HYPOTHESES}

\section{Hypothesis one}

Hypothesis one states that, remuneration is not significantly related to brain drain among health practitioners. The dependent variable is, remuneration, while the independent variable is brain drain. Linear regression analysis was used to test this hypothesis at .05 level of significance, the result of the analysis displayed in Table 6 revealed that remuneration significantly predicted brain drain among health practitioners, $\mathrm{F}(1,249)=9.806$. The correlation is positive and small $(\mathrm{R}=.103)$. More so, this accounts for 10.3 percent of the variance in brain drain among health practitioners. The beta weight $(\beta=.103, t=2.384, p<.05)$ suggests that an increase in refusal of implementing remuneration packages significantly predicts brain drain in the health sector, the adjusted $\mathrm{R}$ Squared value of .010, which is a measure of effect size indicate that 1.0 percent of the variance in brain drain was explained by the model. This implies that, remuneration significantly occasioned brain drain among health practitioners.

Table 6: Linear regression of remuneration and brain drain among health workers

\begin{tabular}{|c|c|c|c|c|c|}
\hline Variable & Mean & SD & r-value & Sig. & \\
\hline Remuneration & 18.61 & 2.68 & 0.103 & .001 & \\
\hline Brain drain & 17.36 & 2.53 & & & \\
\hline \multicolumn{6}{|c|}{ Model summary } \\
\hline Model & $\mathrm{R}$ & R Square & $\begin{array}{l}\text { Adjusted R } \\
\text { Squared }\end{array}$ & $\begin{array}{l}\text { Sd. Error of the } \\
\text { Estimate }\end{array}$ & \\
\hline 1 & .103 & .011 & .010 & 2.67 & \\
\hline \multicolumn{6}{|l|}{ ANOVA } \\
\hline Model & $\begin{array}{l}\text { Sum of } \\
\text { Squares }\end{array}$ & $\mathrm{Df}$ & $\begin{array}{l}\text { Mean } \\
\text { Square }\end{array}$ & $\mathrm{F}$ & Sig. \\
\hline Regression & 70.077 & 1 & 70.077 & 9.806 & .002 \\
\hline Residual & 1625.516 & 249 & 7.145 & & \\
\hline Total & 1695.593 & 250 & & & \\
\hline \multicolumn{6}{|c|}{ Regression coefficients } \\
\hline Model & $\beta$ & Std. Error & Beta & t. & Sig. \\
\hline Constant & 13.624 & .524 & & 27.279 & .000 \\
\hline Brain drain & .116 & .053 & .103 & 2.384 & .002 \\
\hline
\end{tabular}

$* \mathrm{P}<.05 ; \mathrm{df}=1.249 ;$ critical-r $=.011 ;$ critical $-\mathrm{F}=9806$

\section{Hypothesis two}

Hypothesis two states that, workers' safety does not incite brain drain among health practitioners. This hypothesis was analytically tested using Linear regression at .05 . The result showed that the predictor variable (workers' safety) significantly predicts brain drain, $\mathrm{F}(1,249)=56.344, \mathrm{P}<.05$. The correlation is positive and moderate $(\mathrm{R}=.211)$. This therefore accounts for 21.1 percent of the variance in brain drain. The beta weight $(\beta=.121, t=5.160, p<.05)$ suggests that a decrease in workers' safety measures contribute significantly to the prediction of brain drain among health workers, 
the adjusted R Squared value of .045 which is a measure of effect size, indicate that 5.2 percent of the variance in brain drain was explained by the model. This therefore implied that, there is significant relationship between workers' safety and brain drain among health workers.

Table 7: Linear regression of workers' safety and brain drain among health workers

\begin{tabular}{|c|c|c|c|c|c|}
\hline Variable & Mean & SD & r-value & \multicolumn{2}{|l|}{ Sig. } \\
\hline Workers' safety & 18.61 & 2.68 & .231 & \multicolumn{2}{|l|}{.000} \\
\hline Brain drain & 15.32 & 2.86 & & & \\
\hline \multicolumn{6}{|l|}{ Model summary } \\
\hline Model & $\mathrm{R}$ & R Square & $\begin{array}{l}\text { Adjusted } \\
\text { R Squared }\end{array}$ & \multicolumn{2}{|c|}{$\begin{array}{l}\text { Sd. Error of the } \\
\text { Estimate }\end{array}$} \\
\hline 1 & .211 & .045 & .044 & \multicolumn{2}{|c|}{1.725} \\
\hline \multicolumn{6}{|l|}{ ANOVA } \\
\hline Model & $\begin{array}{l}\text { Sum of } \\
\text { Squares }\end{array}$ & Df & $\begin{array}{l}\text { Mean } \\
\text { Square }\end{array}$ & $\mathrm{F}$ & Sig. \\
\hline Regression & 334.782 & 1 & 334.782 & 56.344 & .000 \\
\hline Residual & 1555.067 & 249 & 6.245 & & \\
\hline Total & 1906.938 & 250 & & & \\
\hline \multicolumn{6}{|c|}{ Regression coefficients } \\
\hline Model & $B$ & Std. Error & Beta & t. & Sig. \\
\hline Constant & 13.182 & .362 & & 24.521 & .000 \\
\hline Brain drain & .121 & .041 & .121 & 5.160 & .000 \\
\hline
\end{tabular}

$* \mathrm{P}<.05 ; \mathrm{df}=1,249 ;$ critical-r $=.045 ;$ critical-F $=56.344$

\section{Hypothesis three}

The third hypothesis states that, working equipment does not correlate with brain drain among health practitioners. This was tested using Linear regression at .05 , the result showed that the unavailability of working equipment significantly predicted brain drain among health practitioners, $\mathrm{F}(1,249)=45.45, \mathrm{P}>$. 05 . The correlation is positive and moderate $(\mathrm{R}=$ .435). More importantly, they accounted for 43.5 percent of the variance in brain drain. The beta weights suggest that the non-availability of work equipment will likely increase the chances of brain drain of health practitioners $(\beta=.435, \mathrm{t}=$ $12.691, \mathrm{p}<.05)$, the adjusted R Squared value of .188 which is a measure of effect size, indicate that 18.8 percent of the variance in brain drain was explained by the model. This implies that, there is significant relationship between working equipment and brain drain of health practitioners.

Table 8: Linear regression of working equipment and brain drain among health workers

\begin{tabular}{|c|c|c|c|c|}
\hline Variable & Mean & SD & r-value & Sig. \\
\hline Working equipment & 18.61 & 2.68 & .435 & .000 \\
\hline Brain drain & 18.44 & 2.79 & & \\
\hline \multicolumn{5}{|l|}{ Model summary } \\
\hline Model & $\mathrm{R}$ & R-Square & $\begin{array}{l}\text { Adjusted } \mathrm{R} \\
\text { Squared }\end{array}$ & Sd. Error of the Estimate \\
\hline 1 & .435 & .189 & .188 & 1.728 \\
\hline \multicolumn{5}{|l|}{ ANOVA } \\
\hline Model & $\begin{array}{l}\text { Sum of } \\
\text { Squares }\end{array}$ & Df & $\begin{array}{l}\text { Mean } \\
\text { Square }\end{array}$ & Sig. \\
\hline Regression & 243.188 & 1 & 243.188 & 45.45 \\
\hline Residual & 1332.249 & 249 & 5.350 & \\
\hline Total & 1575.393 & 250 & & \\
\hline \multicolumn{5}{|c|}{ Regression coefficients } \\
\hline Model & $\mathrm{B}$ & Std. Error & Beta & Sig. \\
\hline Constant & 12.624 & .418 & & 20.332 \\
\hline Brain drain & .387 & .036 & .435 & 12.691 \\
\hline
\end{tabular}

$* \mathrm{P}<.05 ; \mathrm{df}=1,249 ;$ critical $\mathrm{r}=.189 ;$ critical $\mathrm{F}=45.45$

\section{DISCUSSION OF FINDINGS}

The statistical result to hypothesis one revealed that remuneration significantly incite brain drain among health practitioners. The finding shows that health practitioners especially in government own hospitals are not properly remunerated. It indicated that remuneration packages such as overtime allowances, call duty allowances, etc are not 
remitted to health workers in the country. More so, it was revealed that the unsatisfactory pay package is responsible for brain drain among health practitioners. It further asserts that inadequate remuneration provokes migration among medical practitioners. It suggests that medical practitioners in developed countries earn better remuneration than their colleagues in Nigeria.

The finding agrees with Noll (2002) who states that appropriate pay system and rewards will help reduce the incidence of brain drain especially among health practitioners. Heneman (1992), Lawler and Jenkins (1992), Agba, et al (2013) aver that "pay in its various forms affects employee-organizational relationship". It was noted that delay in the "payment of employee remuneration has been greeted with widespread" incidence of brain drain. In a similar vein, Murray (2010) reported that remuneration significantly impacts on workers' attitude in the organization. Similarly, Padarath and Chamberlain (2003) posits that remuneration are potentially the most influential and decisive factor responsible for the migration of health professionals. Awases, Gbany, Nyan, and Chatora (2004), Hamada, Maben, McPake and Hanson (2009), put forward that low wages are significant to the migration of health personnel to developed countries, where remunerations are better. This further buttresses the view of Tessema (2010), who maintained that, health personnel feel that salaries they earn abroad simply cannot matched those they earn in their home country.

Data analysis for hypothesis two reveals a significant relationship between workers' safety and brain drain among health practitioners. From the analysis, the value was positive, which indicates that migration of health professionals is prevalent where workers feel threatened in their work places as a result of disease outbreak. It also showed that medical practitioners travel to countries where workers' safety are held in high esteem. Furthermore, it revealed that high-quality care of health professionals in receiving countries is responsible for continuous brain drain among doctors and nurses. It was further justified that health professionals migrate because they are dissatisfied with safety precautions in their hospitals.

This finding was buttressed in the study of Ndagana (2007), Sakir and Fajonyomi (2007) whom included clean and siren environment as well as good working relationship between employer and employee as part of the incentive packages due to workers. Working environment has the capacity to dampen or boost the morale of employee and can significantly contribute to brain drain among health workers. It is evident in the findings of Paterson, West, Lawthorn and Nickel (1997) that the more satisfied workers are with the safety standard in their workplace the better the organization is likely to perform in terms of subsequent profitability and enhanced industrial harmony. The finding equally validated the extensive scientific research of Roelofsen (2002), which states that the provision of safety measures in an establishment reduces injury, absenteeism, turn-over, deviant behaviour, and stoppage of work

The statistical result for hypothesis three unfolded that the non-availability of working equipment significantly incite brain drain among health practitioners. It reveals that inadequate infrastructural facilities, failure of hospital management to provide essential working tools, inability of management to maintain as well as replace damaged equipment, are responsible for brain drain among doctors and nurses. The finding agrees with the study of Manongi, Marchant and Bygbjerg (2006) that health practitioners' grapple with the lack of laboratory facilities and funds to support innovation are more likely to migrate to other health facilities. This finding is also supported by the study of Ikenwilo (2007) who asserts that the issue of inadequacies in healthcare facilities and the enabling work environment are common features of most developing nations. These inadequacies most times push medical practitioners to move to other countries where these facilities are available.

\section{CONCLUSION AND RECOMMENDATIONS}

Empirical evidence in this study reveals that working conditions including remuneration, workers' safety, and working equipment, are significantly responsible for brain drain among health practitioners in Nigeria. While acknowledging that working conditions do motivate the occurrence of brain drain, the study shows that proper and adequate review of remuneration packages could encourage health workers' effectiveness in their organisations. It reveals that the implementation of safety policies in hospitals would curtail the incidence of brain drain. The study also reveals that adequate funding and equipping of hospitals in the country would help health practitioners function effectively and reduce brain drain. Consequent upon these findings, the following recommendations were made: Government should improve on the existing remuneration of health workers in Nigeria. Again, hospital management should introduce and strengthen existing programmes that ensures work safety in hospitals.

\section{REFERENCES}

- Agba, A. M. O. \& Ushie E. M. (2013). Wage differentials and industrial disputes in Nigerian hospitals. IOSR Journal of Business and Management, 11(5), 1-12.

- Agba, A. M. O. \& Ushie, E. M. (2010). Motivational incentives and staff turnover in the hospitality industry in Cross River State, Nigeria. Global Journal of Management and Business Research, 10(8), 18-36.

- Agba, A. M. O., Eteng, F. O., \& Coker, F. G. (2016). Skills training and workers' productivity in Cross River State, Nigeria. FULafia Journal of Social Sciences (Maiden Edition), 327-341. 
- Agba, A. M. O., Mboto, W. A. \& Agba, M. S. (2013). Wages or other conditions: A critical assessment of factors in workers' performance in Nigeria. International Journal of Academic Research in Business and Social Sciences, 3(7), 489-505

- $\quad$ Agba, A. M. O., Nkpoyen, F. \& Ushie, E. M. (2010). Career development and employee commitment in industrial organizations in Calabar, Nigeria. American Journal of Scientific and Industrial Research, 1(2), $105-114$.

- $\quad$ Agba, A. M. O., Ushie, E. M., Agba, M. S. \& Nkpoyen, F. (2010). Privatization, job security and performance efficiency of privatized enterprises in Nigeria. Researchers World-Journal of Arts Science and Commerce, 1(1), 95-102.

- $\quad$ Agba, A. M. O., Ushie, E. M., Ushie, M. A., Bassey, A. O. \& Agba, M. S. (2009). Human development trend in Nigeria: The need for concrete implementation of seven the point agenda. Nigerian Journal of Social and Development Issues, 6(1), 15-28.

- Angioha, P. U., Nwagboso, S. N., Ironbar, A. E. \& Ishie, E. U. (2018). Underemployment: A sociological and policy analysis of workers well-being in hospitality industry in Calabar, Cross River State, Nigeria. IOSR Journal of Humanities and Social Science (IOSR-JHSS), 23(6), 57-66.

- Attah, F. M. \& Angioha, P. U. (2019). Examining the level of relationship between working condition predictor variables; remuneration, working hours, office design, job security and workers wellbeing and productivity in commercial banks. International Journal of Scientific and Research Publications (IJSRP), 9(5), DOI: http://dx.doi.org/10.29322/IJSRP.9.05.2019.p896.

- Awases, M.; Gbany, A.; Nyam, J. \& Chatora, R. (2004). Migration of health professionals in six countries: A synthetic report. Africa, Brazzaville: WHO General Office for Africa.

- Bureau of Labour Statistics (2000). National census of fatal occupational injuries, 1999 (USDL Publication no. 00-236). Washington, DC: Author.

- Carvantes, M. \& Dominique G. (2002). The brain drain: Old myths, new realities. OECD Obsava. Online available at: http://www.oecdobsava.org. Retrieved 16/12/15.

- $\quad$ Dimaya, R.; McEwen, M.; Curry, L. \& Bradley, E. (2012). Managing health worker migration: A qualitative study of the Philippines response to nurse brain drain. Journal of Human Resources for Health, 47(10), 2-8.

- Hall, P. (2005). Brain drain and brain gains: Causes, consequences, policy. International Journal of Social Economics, 32(11):939-95.

- Halsall, P. (1997). Modern history sourcebook: Summary of Wallerstein on world system theory. Online available at: www.fordnam.edu/../walersteinasp.

- Hamada, N., Maben, J. McPake, B. \& Hanson, K. (2009). International flow of Zambian nurses. Human Resource Health, 83, 7-83.

- Ikenwilo, D. (2007). Brain drain: Painting a picture for Africa. Nairobi: African Technology Policy Studies Network.

- International Labour Organization (ILO, 2012). Estimating the economic costs of occupational injuries and illnesses in developing countries: Essential information for decision-makers. Geneva: International Labour Office.

- Kampert P (2008). Good work environment improves satisfaction, and productivity. Tribune June 8

- Khwaja, Y. \& Scaramozzino, P. (2003). Unknown Talents and the Brain Drain: The Informational Role of Migration. Centre for Financial and Management Studies, 1-18

- Kiraya, V. (2000). Should I stay or should I go: migration under uncertainty: A new approach. Online available at: http: www.saasac.ulc/economics/research/workingdoctorapas. Retrieved 19/12/15.

- $\quad$ Lawler, E. E. III, \& Jenkins, G. D., Jr. (1992). Strategic reward systems. In M. D. Dunnette \& L. M. Hough (Eds.), Handbook of industrial and organizational psychology (pp. 1009-1055). Palo Alto, CA, US: Consulting Psychologists Press.

- $\quad$ Lechtner, F. J. (2009). Globalization: The making of world society. New York: Wiley Blackwell

- Lusale, V. D. (2007). The Brain Drain of Zambian health workers: Why do Zambian health workers migrate abroad? Available online at: https://www.medicusmundi.ch/de/bulletin/mms-bulletin/gesundheitspersonal-diekrise-uberwinden/human-resources-for-health-beyond-the-declarations-symposium-am-schweizerischentropeninstitut-21-maerz-2007/the-brain-drain-of-zambian-health-workers

- Manongi, R. N.; Marchant, T. C. \& Bygbjerg, I. C. (2006). Improving motivation among primary health care workers in Tanzania: A health worker perspective. Human Resources for Health, 4(6). Online available at: http://www.human-resourceshealth.com/content/4/1/6. Accessed 6/9/15.

- Mensah, K., Mackintosh, M. \& Henry, L (2005). The 'skills drain' of health professionals from the developing world: A framework for policy formulation. London: Grayston Centre.

- Meyer, J. B. \& Brain, M. (1999). Scientific Diaspora: A new approach to the brain drain. Management of Social Transformation Discussion Paper No. 41. Paris: UNESCO. 
- Mills, E. J., Kanters, S., Hagopian, A., Bansback, N., Nachega, J., Alberton, M., Au-Yeung, C. G., Mtambo, A., Bourgeault, I. L., Luboga, S., Hogg, R. S. \& Ford, N. (2011). The financial cost of doctors emigrating from SubSaharan Africa: Human capital analysis. British Medical Journal, 343:7031.

- $\quad$ Naicker, S., Plange-Rhule, J., Tutt, R. C. \& Eastwood, J. B. (2009). Shortage of healthcare workers in developing countries-Africa. Ethnicity \& Disease, 19, 60-64

- Ndagana, J. M. (2007). Behavioural pattern of non-academic staff of Federal Universities in Nigeria to Job dissatisfaction. Educ. Forum, 10(1), 1677-1184.

- Noll, R. G. (2002). The economics of promotion and relegation in sports leagues: The case of English football. Journal of Sports Economics, 3(2):169-203 .

- OECD (Organisation for Economic Co-operation and Development). 2002. International migration of physicians and nurses: Causes, consequences, and health policy implications. Paris.

- Padarath, A. \& C. Chamberlain. 2003. Health personnel in Southern Africa: Confronting maldistribution and brain drain. EQUINET Discussion Paper Number 3. Online available at: http://ww.medact.org/content/health/documents/brain_drain/Padarath....pdf. Accessed 8/9/16.

- $\quad$ Patterson, M. G., West, M. A., Lawthom, R. \& Nickell, S. (1997). Impact of people management practices on business performance. Wiltshire: Cromwell Press

- Roelofsen, P. (2002). The impact of office environments on employee performance: The design of the workplace as a strategy for productivity enhancement. Journal of Facilities Management, 1, 247-264. https://doi.org/10.1108/14725960310807944

- $\quad$ Sakir, A. \& Fajonyomi A, A. (2007). Career growth and financial benefit as factors motivating grade II teachers in Borno State to return to further training. Educ. Forum, 10(1):21-25.

- Tessema, M. (2010). Causes, challenges and prospects of brain drain: The case of Entrea-International Journal of Migration, 48(3), 131-157.

- United States Census Bureau. (2000). Statistical abstract of the United States: 2000 (120 ${ }^{\text {th }}$ ed.). Washington, DC: USCB

- Wallerstein, I. (1974). The Modern World System: Capitalist Agriculture and the Origins of the European WorldEconomy in the 16th Century. New York: Academic Press.

- World Health Organisation (WHO) $\left(2006^{a}\right)$. The World Health Report: Working together for health. Geneva: WHO.

- World Health Organization (WHO) $\left(2006^{\mathrm{b}}\right)$. Doctor-patient in Africa. World Health Statistics. Online available at: http://www.who.int/whosis/whostat2006/en/index.html. Accessed 9/11/2015. 